JURNAL HUKUM

RUTH KAMBUAYA

\title{
THE LEGAL STANDING OF THE ADAT COMMUNITY OF YAWAONAT AS A PROPOSER IN THE MATERIAL EXAMINATION OF THE ARTICLE 20 LETTER A OF THE LAWS NUMBER 21/2001 IN THE CONSTITUTIONAL COURT
}

Case Study: The legitimacy of Indigenous People Yawa OnatE Yapen Waropen Against Komaruddin Watubun As the native of Papuan based on Papua Special Autonomy Law

\begin{abstract}
The substance of legislation is a written legal norm which has a binding and constant legal power. Substantially, the Article 20 section 1 letter a of the Laws Number 21/2001 has violated the constitutional rights of the adat community of Yawaonat. In this connection the adat community has made a proposal for material examination against Laws Number 21/2001 to the Constitutional Court. This study describes the rights of the adat community in accommodating outsiders (non-Papuan people) to become the Native of Papuans based on the adat law which has been accommodated in the Laws Number 21/2001. The material examination conducted by the Constitutional Court decided that the significance for recognizing outsiders to become the Native of Papuans if it is not well signified will create constitutional losses for outsiders who have been recognized as the native Papuans and can harm the constitutional rights of the adat community. This is a normative legal study. The legal sources employed for this study was the legal primary and secondary sources. The analysis was done systematically and interpretatively with juridical evaluations. The legal standing of the adat community of Yawaonat as a proposer in the session of the Constitutional Court is based on the specifications of Article 51 section 1 of the Laws Number 24/2003 with reference to the Laws Number 8/2011 concerning Constitutional Court. The rights of the adat community which is violated covers the constitutional rights given by the 1945 Constitution and the rights by Laws Number 21/2001.
\end{abstract}

Key word: Legal standing: Adat community: Laws examinat 


\section{BAB I}

\subsection{PENDAHULUAN}

Secara sosiologi eksistensi masyarakat hukum adat merupakan suatu sistem sosial, yang menjadi wadah dari polapola interaksi sosial atau hubungan interpersonal maupun hubungan sosial. Masyarakat hukum adat adalah masyarakat yang timbul secara spontan diwilayah tertentu, yang berdirinya tidak ditetapkan atau diperintahkan oleh penguasa yang lebih tinggi atau penguasa lainnya,dengan rasa solidaritas yang sangat besar diantara para anggota masyarakat sebagai anggota luar dan menggunakan wilayahnya sebagai sumber kekayaan yang hanya dapat dimanfaatkan sepenuhnya oleh para anggotanya. (Hilman Hadi Kusuma $1980)$.

Masyarakat hukum adat terdiri dari tiga komponen penting yaitu Masyarakat /society merupakan sekelompok manusia yang telah lama hidup dan bekerjasama,

sehingga mereka itu mengorganisasikan dirinya dan berpikir tentang dirinya sebagai suatu kesatuan social dengan batas-batas tertentu. (ii) Hukum /law merupakan seperangkat aturan yang memuat tentang sejumlah norma-norma tertentu, bertujuan mengatur tata pergaulan hidup, mempunyai sanksi yang sifat mengikat diantara para kelompoknya. (iii) Adat adalah merupakan suatu kebiasaan /tradisi yang dilakukan secara berulang-ulang. Sehingga dapat disimpulkan bahwa masyarakat hukum adat merupakan suatu kelompok manusia yang memiliki budaya ( culture) tertentu diantara para anggotanya yang dilakukan secara turun temurun berdasarkan aturan/normanorma hukum adat yang mengikat diantara para anggotanya. 
Keberadaan masyarakat hukum juluki oleh pelayar bangsa Prortugal adat yang dimaksud dalam kajian ini dengan julukan "Isla de Ora” artinya “ adalah masyarakat hukum adat Orang Pulau Emas” dan dari bahasa Spanyol “ Asli Papua yang terdiri dari 263 suku- Nova” yang artinya baru dan Guinea suku asli di Provinsi Papua. artinya tanah atau tempat dan Orang Eksistensi masyarakat hukum adat Belanda menamakan New Guinea Tanah Papua memiliki arti penting dalam sistem penyelenggaraan pemerintahan Provinsi Papua dan secara umum dalam sistem pemerintahan Negara Kesatuan Republik Indonesia.

Masyarakat hukum adat adalah, warga masyarakat asli Papua yang sejak kelahirannya hidup dalam wilayah tertentu dan terikat serta tunduk kepada hukum adat tertentu dengan rasa solidaritas yang tinggi diantara para anggotanya ( Pasal 1 huruf r UU Otsus Papua).

Secara antropologis Orang Asli Papua berasal dari ras negroit rumpun Melanesia. Nama Papua berasal dari kata Melayu, yaitu: “Pua-Pua” yang berarti rambut keriting. Bahkan Pulau Papua di Papua (Rainer Scheunemann ; 2004:30).

Dalam literature lain pun menyebutkan bahwa masyarakat hukum yang sederhana memiliki adat yang sungguh-sunguh, halus dan kompleks seperti hubungan-hubungan keluarga ( H.Lili Rasjidi \& I.B.Wyasa Putra ; 2003: 155).

Dari beberapa pendapat diatas dapat disimpulkan ciri-ciri suatu masyarakat hukum adat adalah sebagai berikut:

1. Mendiami suatu wilayah tertentu;

2. Merupakan suatu kesatuan/kelompok tertentu.

3. Mempunyai ciri-ciri geneologi tertentu

4. Mempunyai adat-istiadat tertentu. dan 
5. Mempunyai sistem pemerintahan adat tersendiri.

Masyarakat hukum adat Papua menjalani kehidupannya sebagai suatu system adat yang sifatnya kompleks dan dijalankan sesederhana mungkin, mereka hidup secara teratur sesuai dengan hukum adat yang berlaku di tiap-tiap suku/etnis. Ciri khas masyarakat hukum adat Papua dapat bedakan melalui tata cara penyelenggaraan pemerintahan adat masing-masing suku/etnis berdasarkan adat-istiadat masing-masing suku/etnis di Provinsi Papua. Dalam rangka mengakomodir mempertahankan eksistensi suku/etnis serta melindungi hak-hak masyarakat hukum adat yang terdiri dari 236 suku/etnis maka Majelis Rakyat Papua (MRP) hadir sebagai lembaga kultural masyarakat hukum adat yang berfungsi sebagai lambang kultural guna memproteksi hak-hak orang asli papua secara individu maupun kelompok.
Hak secara kelompok inilah yang didefenisikan sebagai hak-hak masyarakat hukum adat sebagaimana termuat dalam Pasal 19 Undang-Undang Nomor 21 Tahun 2001 jo UndangUndang Nomor 35 Tahun 2008 tentang Otonomi Khusus Provinsi Papua ( UU Otsus Papua).

Kehadiran Majelis Rakyat Papua dalam kerangka structural pemerintahan Provinsi Papua guna memperkuat system penyelenggaraan otonomi Khusus Papua, salah satu tugas MRP adalah memberikan pertimbangan dan persetujuan kepada bakal calon gubernur dan wakil gubernur Provinsi Papua yang secara

antropologis adalalah orang asli Papua. Berdasarkan wewenang tersebut pada tahun pada tanggal 18-November- 2005 MRP mengeluarkan $\quad$ SK No.06/MRP/2005 yang menolak Komaruddin watubun sebagai bakal calon wakil gubernur Provinsi Papua 
karena yang tersebut bukanlah orang asli

Papua. Keputusan MRP tersebut secara hukum adat telah merugikan hak konstitusional masyarakat hukum adat Yawa Onate yang telah memberikan pengakuan secara hukum adat kepada Komaruddin Watubun sebagai orang asli Papua sesuai dengan pasal 1 huruf $t$ UU Otsus-Papua. Oleh karena itu kedudukan hukum (legal standing) masyarakat hukum Yawaonat sebagai pemohon terhadap uji materil Pasal 20 Ayat (1) UU Otsus-Papua di Mahkamah Konstitusi menarik untuk dikaji.

\subsection{RUMUSAN MASALAH}

1. Apakah kedudukan hukum Masyarakat hukum Adat Yawaonat Konstitusi ?
2. Hak Konstitusional masyarakat hukum adat Yawaonat apakah yang telah dilanggar oleh Majelis Rakyat Papua?

\subsection{METODE PENELITIAN}

Dilihat dari substansi kajian ini, penelitian ini merupakan penelitian hukum normatif yang berfokus pada pada peraturan perundang-undangan. Bahan hukum yang digunakan dalam penelitian ini adalah bahan hukum primer dan yang berfokus pada Undang-Undang Dasar Tahun 1945 dan UU N0 21 Tahun 2001 dan bahan hukum sekunder meliputi jurnal hukum, makalah, buku-buku teks hukum yang materinya relevan dengan materi/substansi yang dikaji. 


\section{BAB II}

\section{HASIL DAN PEMBAHASAN}

\section{A. Kedudukan Hukum (Legal Standing) Masyarakat Hukum Adat Yawaonat Dalam Konstitusi.}

Dalam bukunya yang berjudul "The legal system a social scince perspective” Tentang “Teori Hukum” ( Lawrence Friedman 1759; 15 ) menyebutkan bahwa Legal Culture (budaya hukum) atau "Komponen budaya hukum" (legal culture), refers, then, to those parts of general culture, customs, opinion, ways of doing and thiking, that bend social forces toward or away from the law and in particular ways" (bahwa budaya hukum adalah bagian dari budaya umumnya, yang berupa adat -istiadat, pandangan, cara berpikir dan tingkah laku, semua itu dapat membentuk kekuatan sosial yang bergerak mendekati hukum dan cara-cara tertentu. Ini berarti bahwa sikap perilaku manusia ataupun kebiasaankebiasaan yang dapat membentuk kekuatankekuatan sosial untuk mentaati hukum atau sebaliknya melanggar hukum).

Di Indonesia sampai dengan saat ini belum ada undang-undang yang dibentuk untuk mengatur kesatuan masyarakat adat, namun hal tersebut tidak berarti bahwa hakhak masyarakat hukum adat dapat diabaikan oleh pemerintah. Secara implicit Penghargaan terhadap hak-hak masyarakat hukum adat dapat ditemui dalam Pasal 51 UU No.24 Tahun 2003 Tentang Mahkamah Konstitusi dan Pasal 67 dan penjelasannya yang terdapat dalam UU No.41 Tahun 1999 Tentang Kehutanan.

Pengakuan eksistensi masyarakat hukum adat Yawa Onate dijamin oleh legal formal peraturan perundang-undangan sebagai berikut:

1. Secara konstitusional negara telah memberikan pengakuan dan penghormatan terhadap hak-hak masyarakat hukum adat. Pengakuan terhadap eksisitensi masyarakat hukum adat merupakan suatu pengakuan dan perlindungan hukum sebagaimana diatur dalam Undang-Undang Dasar Negara Tahun 1945 yang termaktub dalam Pasal 18-B ayat (2) yang menentukan bahwa "Negara mengakui dan menghormati kesatuan masyarakat hukum adat beserta hak-hak tradisionalnya sepanjang masih hidup dan sesuai dengan perkembangan masyarakat dan prinsip-prinsip Negara Kesatuan Republik Indonesia, yang diatur dengan dalam undang-undang. 
Berdasarkan uraian substansi Pasal 18-B ayat (2) UUD Tahun 1945 maka ada 3 unsur penting yang menjadi landasan yuridis pengakuan terhadap masyarakat hukum adat yaitu:

a. Merupakan suatu Kesatuan Masyarakat Hukum Adat Yaitu agar dapat mempertahankan eksistensi kelompoknya secara turun-temurun sebagai suatu bagian / system yang berkelompok maka tiap suku/etnis harus mampu mempertahankan adatistiadatnya secara turun temurun.

b. Masih hidup dan sesuai dengan perkembangan masyarakat.

Negara memberikan jaminan kepastian hukum kepada masyarakat sebagai suatu penghormatan kepada masyarakat hukum adat sepanjang keberadaan masyarakat hukum adat itu masih hidup dan berkembang, artinya apabila kesatuan masyarakat tersebut sudah tidak dapat lagi mempertahankan keberadaannya ditengah-tengah arus globalisasi perkembangan Negara maka kesatuan masyarakat tersebut dengan sendirinya akan hilang.

c. Yang diatur dengan dalam undangundang.

Dalam Undang-Undang Otonomi Khusus Papua pengakuan terhadap eksistensi masyarakat hukum adat Papua sebagaimana termuat dalam Pasal 1 huruf r yang menentukan bahwa Masyarakat hukum adat adalah warga masyarakat asli Papua yang sejak kelahirannya hidup dalam wilayah tertentu dan terikat serta tunduk kepada hukum adat tertentu dengan rasa solidaritas yang tinggi diantara para anggotanya.

Dalam Undang-Undang Otsus -Papua secara eksplicit tidak diatur tentang hak-hak masyarakat hukum adat Papua namun hakhak masyarakat hukum adat Papua akan diatur secara implicit dalam Perdasus No.23 Tahun 2008 Tentang Hak Ulayat Masyarakat Hukum Adat dan Hak Perorangan Warga Masyarakat Adat atas tanah.

Beradasarkan uarain landasan konstitusi tentang perlindungan terhadap Masyarakat Hukum Adat diatas, maka Kedudukan Hukum (Legal Standing) Masyarakat Yawa Onat dalam uji materil Pasal 20 ayat (1) huruf a UU Otsus-Papua No.21 Tahun 2001 di Mahkamah Konstitusi didasarkan pada Ketentuan Pasal 51 Ayat (1) UU MK yang menyebutkan bahwa Pemohon pihak yang menganggap hak dan/atau kewenangan konstitusionalnya dirugikan oleh berlakunya suatu undang-undang, yaitu:

a. Perorangan warga negara Indonesia; 
b. Kesatuan Masyarakat Hukum Adat Konstitusional" adalah: Hak-hak yang diatur sepanjang masih hidup dan sesuai dalam UUD 1945. Putusan MK dengan perkembangan prinsip NKRI : $\quad$ Nomor.006/PUU/V/2007 tentang kerugian

c. Badan hukum publik maupun Privat, konstitusional yang dimaksud dalam Pasal 51 atau

d. Lembaga Negara. ayat(1) \& Penjelasan Pasal 51(1) UU MK meliputi:

Penjelasan Pasal 51 ayat (1) UU MK

yang menyebutkan bahwa "Hak

a. Adanya hak dan/atau kewenangan konstitusional potensial yang menurut penalaran yang wajar dan pemohon yang diberikan oleh UUD 1945; dapat dipastikan akan terjadi.

b. Adanya hak dan/ atau kewenangan konstitusionad. Adanya kemungkinan bahwa dengan tersebut oleh pemohon dianggap dirugikan oleh dikabulkannya permohonan, maka berlakunya Undang-Undang yang dimohonkan kerugian konstitusional seperti yang pengujiannya. didalilkan tidak akan atau tidak lagi

c. Kerugian konstitusional tersebut bersifat spesifik terjadi.

( khusus) dan actual atau setidak-tidaknya

\section{B. Hak Konstitusional Masyarakat \\ Hukum Adat Yawaonat yang dilanggar oleh Majelis Rakyat Papua.}

Sejak pemberlakuan UU Otsus-Papua sebagaimana telah diubah dengan UU No.35 Tahun 2008 telah hadir beberapa aturan hukum berupa Perdasi ( Peraturan Daerah Provinsi) dan Perdasus ( Peraturan daerah Khuusus) yang telah dibentuk oleh pemerintahan daerah Provinsi Papua guna merealisasikan substansi UU Otsus- Papua.

Kehadiran UU Otsus Papua ditinjau dari segi output kemanfaatan memiliki dua (2) dampak dalam lapangan public pemerintahan daerah Provinsi Papua (Pemda-Provinsi Papua) antara lain: (1) Dampak Positif yaitu dimana UU Otsus merupakan sarana/alat pemerintah pusat guna meningkatkan kesejahteraan masyarakat Papua dan dampak (2) yaitu dampak negative yaitu bahwa banyak pula rumusan dari UU Otsus -Papua yang mengandung norma kabur (vague normen). Kekaburan norma dalam UU Otsus-Papua 
pun tak jarang menimbulkan kontrafersi penerapan UU Otsus di lapangan hukum dan tak jarang pula menyulut berbagai sengketa organ kelembagaan daerah dalam pelaksanaan wewenang institusional. Akibat lain dari banyaknya norma kabur sering pula memicu konflik / pertentangan (leemten van normen) diantara peraturan perundang-undangan baik secara vertical maupun horizontal, pertentangan norma pun tidak jarang menimbulkan kerugikan konstitusional secara individual, kelompok maupun masyarakat Provinsi Papua pada umumnya. Lemahnya kepastian hukum dalam UU No.21 Tahun 2001 melahirkan produk hukum yang tidak berkarakter yuridis formal dan responsive sesuai dengan landasan filosofis pembentukan Undang-Undang No.21 Tahun 2001.

Keberadaan Masyarakat hukum adat Yawa Onate Merupakan suatu Kesatuan Masyarakat Hukum Adat yang terdiri dari 18 suku/etnis yang mendiami kepulauan Yapen Waropen, hingga saat ini masih hidup dan berkembang, mereka masih mempertahankan adat-istiadatnya termasuk hak-hak ada yang diperolehnya secara turun temurun (sistem pemerintahan adat). Uraian substansi kedudukan hukum (legal standing) diatas memperkuat keberadaan masyarakat hukum adat Yawaonat sebagai suatu komunitas (kelompok) tertentu dan hidup dalam suatu wilayah teritorial Yapen Waropen dan mempunyai pemerintahan adat sendiri yang dilakukan secara turun- temurun.

Hak masyarakat hukum adat Yawa Onate yang dilanggar oleh adalah hak dalam mengakomodir / mengangangkat / mengukuhkan seseorang yang notabennya bukan Orang Asli Papua menjadi Orang Asli Papua sesuai dengan hak-hak masyarakat sebagai mana ditentukan dalam rumusan Pasal 1 huruf t UU Otsus-Papua.

Dalam adat-istiadat Orang asli Papua perihal mengdopsi anak atau yang dalam bahasa ibu lebih dikenal dengan sebutan “angkat anak" bukanlah merupakan suatu hal yang "tabu'. Tradisi mengadopsi anak berdasarkan garis keturunan Patrilineal ( masyarakat yang susunan pertalian darahnya mengikuti garis keturunan bapak atau garis keturunan laki-laki); Matrilineal (masyarakat yang susunan pertalian darahnya mengikuti garis keturunan ibu atau garis keturunan wanita) ; maupun parental, merupakan suatu tradisi yang telah dilakukan secara turun temurun sejak dahulu sebelum masyarakat Papua mengenal system pemerintahan formal maupun sesudah adanya system pemerintahan formal. Demikian pula dalam hal budaya mengakomodir/ mengangkat anak/ adopsi anak dari Orang non Papua menjadi Orang asli Papua pun telah dilakukan sejak zaman 
nenek moyang orang asli Papua. Tradisi mengadopsi anak hingga saat ini pun masih tetap dilakukan, adapun tujuan megadopsi anak antara lain guna meneruskan keturunan dan mempererat tali kekeluargaan diantara para anggota masyarakat hukum adat Papua.

Budaya mengadopsi anak/angkat anak dalam suku Yawa Onate yang telah dilakukan oleh masyarakat hukum adat Yawa Onate dan hal tersebut merupakan suatu tradisi adat/ritual adat yang telah dilakukan secara turun temurun. Prosesi pengangkatan anak pun dapat dilakukan dengan cara yang berbeda-beda sesuai dengan adat-istiadat tiap-tiap kelompok masyarakat adat tersebut, hak mengangkat anak/ mengadopsi anak inilah yang disebut hak adat, hak tersebut berlaku diantara para anggota/kelompok warga tersebut, dan kepatuhan terhadap aturan hukum tersebutlah yang disebut hukum adat.

Secara adat terkait pengakuan seseorang sebagai anggota masyarakat hukum adat hanya dapat dilakukan dengan 2 cara yaitu (i) berdasarkan faktor geneologis yaitu kesatuan masyarakat hukum adat yang mempunyai hubungan pertalian darah/ atau yang lebih dikenal lagi dengan pertalian keturunan dan (ii) berdasarkan faktor teritorial yaitu kesatuan masyarakat hukum adat yang mendiami dusun atau gabungan wilayah, mereka itu juga merupakan suatu golongan, suatu kesatuan pembelaannya, karena ia datang dan bertempat tinggal dengan golongan masyarakat dusun tersebut dan diakui dalam ikatan masyarakat tersebut. ( Ter Haar dalam Soebakti Poesponoto 1985 :29)

Demikian halnya dengan Pengakuan adat Yawa Onat terhadap Komaruddin Watubun sebagai Orang Asli Papua oleh masyarakat hukum adat Yawa Onat yang dilakukan oleh David Barangkea didasarkan faktor teritorial, hal tersebut karena orang tua yang berangkuan telah hidup lama secara turun temurun ditanah Papua. Selain itu pengakuan masyarakat hukum adat Yawa Onate terhadap Komarudin Watubun didasarkan pada pengakuan Komaruddin Watubun secara hukum dikatakan sesuai dengan ketentuan : (i) Pasal 1 huruf q UU Otsus Papua yang menentukan bahwa "Hukum adat adalah aturan atau norma norma hukum tidak tertulis yang hidup dalam masyarakat, mengatur, mengikat dan dipertahankan serta mempunyai sanksi. (ii) Pasal 1 huruf $\mathrm{t}$ UU Otsus Papua yang menentukan bahwa Orang asli Papua adalah "Orang yang berasal dari rumpun ras Melanesia yang terdiri dari suku-suku asli di Provinsi Papua dan /atau orang yang diterima dan diakui sebagai orang asli Papua oleh masyarakat hukum adat Papua” : 
Kalimat dan/atau dalam rumusan

Pasal 1 huruf $\mathrm{t}$ merupakan norma hukum positif yang telah mempunyai kekuatan hukum tetap dalam UU Otsus-Papua. Sehingga Ketentuan tersebut mengkategorikan dua macam pengertian orang asli yaitu: (i) Pertama, orang asli Papua dari rumpun ras Melanesia (ii) Kedua orang-orang dari daerah lain yang diterima dan diakui sebagai orang asli melalui suatu upacara adat.

Kesalahan dalam menginterpretasikan dan melaksanakan materi muatan Pasal 20 ayat (1) huruf a dan Pasal 1 huruf t UU Otsus Papua yang dilakukan oleh Majelis Rakyat Papua (MRP) dengan mengeluarkan Keputusan Nomor 06/MRP/2005 tanggal 18 Nopember 2005 yang menyatakan bahwa Komaruddin Watubun bukan orang asli Papua telah melanggar hak konstitusional masyarakat hukum adat Yawa Onat, Keputusan MRP tersebut tersebut dilakukan tanpa adanya komunikasi dan klarifikasi kepada David Barangkea sebagai pemegang kewenangan Masyarakat Hukum Adat Yawa Onat maupun pihak lain mengetahui norma hukum Masyarakat Hukum Adat Yawa Onat. Keputusan MRP yang menyatakan Komaruddin Watubun bukan orang asli Papua telah merugikan hak konstitusioanal Komarudin Watubun.
Hak konstitusional masyarakat hukum adat suku Yawa Onat yang dirugikan oleh MRP adalah hak dalam mengakomodir orang non Papua menjadi orang asli Papua sesuai dengan ketentuan pasal 1 huruft UU Otsus Papua. Kebijakan mengakomodir orang non Papua menjadi orang asli Papua merupakan wewenang setiap masyarakat hukum adat yang telah dilakukan secara turun temurun berdasarkan hukum adat

Berdasarkan Pendapat Mr.B.Ter Haar dan ketentuan Pasal 1 huruf $\mathrm{t}$ UU Otsus-Papua maka Komaruddin Watubun telah diakui sebagai anak adat suku yawaonat, sesuai dengan pengakuan adat tersebut maka orang-orang yang diakui dan diterima sebagai anggota masyarakat adat mempunyai persamaan dengan Orang Asli Papua yang berasal dari ras melanesia, dengan demikian ketentuan int berkarakter responsive karena:

1. Mengakomudir anggota masyarakat dari daerah lain di Papua untuk disyahkan sebagai orang asli Papua.

2. Menjamin hak konstitusional (HAM Politik) untuk berpartisipasi dalam pemerintahan termasuk mencalonkan diri sebagai Calon Gubernur/Wakil Gubernur.

3. Menjunjung tinggi asas equality before the law sebagaimana diakui dalam negara hukum dalam sistem hukum Anglosaxon The Rule of Law maupun menurut konsep Negara Hukum 
"rechtsstaat" yang menempatkan perlindungan HAM sebagai salah satu unsur penting dalam Negara Hukum.

4. Persamaan merupakan salah satu jenis HAM yang dalam Pasal 4 Undang-Undang No.39 Tahun 1999 terkategori sebagai HAM absolut yang bersifat (universal) yang karena itu tidak dapat dikurangi dalam keadaan apapun dan oleh siapapun.

Setelah melakukan pengujian materil terhadap pasal-pasal dalam UU Otsus-Papua seperti yang tersebut diatas Mahkamah Konstitusi dalam pertimbangan hukumnya Nomor 29/PUU-IX/2010 Permohonan judicial review terhadap Pasal 20 ayat (1) huruf a UU No 21 Tahun 2001 menyatakan bahwa Pasal 20 ayat (1) huruf a UU Otsus Papua tidak mempunyai kekuatan hukum mengikat. Artinya dari segi penerapan Pasal 20 ayat (1) UU Otsus-Papua bahwa wewenang untuk menyatakan status social sesorang berdasarkan UU Otsus bukanlah wewenang Majelis Rakyat Papua (MRP). MRP dikatakan mempunyai wewenang guna memproteksi hak-hak orang asli Papua sesuai dengan ketentuan UU Otsus-Papua, hal itu bermakna bahwa MRP hanya dapat melakukan hal-hal yang ditentukan baginya sesuai dengan wewenang yang ditentukan baginya selain dari pada itu MRP tidak dapat bertindak diluar wewenangnya.
Berdasarkan Keputusan Mahkamah Konstitusi diatas maka MRP wajib mengakui Komaruddin Watubun sebagai orang asli Papua, karena yang bersangkutan telah diakui dan dikukuhkan oleh masyarakat hukum adat Yawa Onat dalam suatu upacara adat. Sebagai konsekuensi kekaburan norma dalam Pasal 20 ayat (1) huruf a dan Pasal 1 huruf t UU Otsus-Papua tersebut, dari perspektif Perancangan Peraturan Perundang-undangan "Legislative drafting" menimbulkan masalahmasalah sebagai berikut:

1. Multi interprestasi

2. Melanggar asas kepastian hukum

3. Keputusan MRP tentang pemberian pertimbangan dan persetujuan bertentangan dengan Pasal 18-B Ayat (2) dan Pasal 28-D Ayat (3) Undang-Undang Dasar Negara Republik Indonesia Tahun 1945.

4. Keputusan MRP No 06/MRP/2005 dikatakan telah melanggar hak konstitusional kesatuan masyarakat hukum adat Yawa Onat yang kepemimpinan tradisionalnya dipercayakan kepada David Barangkea dan juga melanggar hak konsttitusional seluruh kesatuan masyarakat hukum adat yang mendiami tanah Papua yang dijamin Pasal 18-B ayat (2) UUD 1945, serta pada saat yang 
bersamaan melanggar hak konstitusional sebagai warga negara

5. Dalam sudut Hukum administrasi Negara kemungkinan tindakan MRP menimbulkan kesewenang-wenangan karena MRP tidak mempunyai wewenang untuk menentukan Komarudin Watubun bukan orang asli Papua

6. Tindakan rechtshandelingan yang dilakukan oleh MRP berdasarkan Keputusan No.06/MRP/2005 yang mengatakan Komarudin Watubun bukan orang asli Papua dikatakan sebagai tindakan diskriminasi sesuai dengan Pasal 1 angka 3 UU HAM.

Pengukuhan Komaruddin Watubun oleh Masyarakat hukum adat Yawa Onate bukan menjadi rintangan maupun ancaman bagi kemajuan pembangunan di Provinsi Papua, tetapi justru merupakan modal bagi upaya mencapai kemajuan pembangunan, Uji Materil UU Otsus -Papua di Mahkamah Konstitusi oleh masyarakat hukum adat Yawaonat merupakan bagian dalam rangka penegakan hukum dan dalam rangka mempertahankan hak-hak masyarakat hukum adat sebagai bentuk perlindungan HAM budaya.

Uraian analisis diatas diharapkan dapat memberikan acuan bagi MRP dalam pelaksanaan tugas dan wewenangnya. Dalam pelaksanaan tugas dan wewenang MRP wajib dijunjung tinggi empat (4) fungsi utama keanggotaan MRP dalam melindungi hak-hak orang asli Papua secara individu maupun kelompok. 4 fungsi tersebut adalah sbb:

1. Fungsi Perlindungan terhadap hak-hak orang asli Papua; Perlindungan/proteksi ini diperlukan karena proses modernisasi maupun pembangunan selama ini tidak banyak menyentuh dan cenderung memarginalkan /meminggikan orang asli Papua serta mulai menghancurkan struktur adat-istiadat orang asli Papua.

2. Fungsi Affirmative, untuk menyusun langkah-langkah dan kebijakan khusus yang beperpihak terhadap orang asli Papua.

3. Fungsi Representasi, dimana anggota MRP merupakan representasi yang paling nyata, sekaligus yang membedakan antara MRP dengan DPRP yang merupakan representasi partai politik dan perwakilan dari seluruh penduduk yang tinggal di Provinsi Papua.

4. Fungsi Partisipatif yaitu bahwa keanggotaan orang asli Papua dalam MRP diharapkan agar mampu menyalurkan aspirasi dan kepentingan orang asli Papua dalam partisipasi untuk pembangunan di Papua. Kelembagaan MRP lahir ditengahtengah pergolakan reformasi pemerintahan 
Indonesia, MRP merupakan lembaga aspirasi yang dibentuk bentuk berdasarkan kebutuhan masyarakat pribumi Papua untuk menyalurkan hak-hak orang asli Papua.

Berdasarkan keempat ( 4 ) fungsi tersebut seharusnya MRP mempertimbangkan secara baik status social masyarakat hukum adat mana yang telah mengakomodir Komaruddin Watubun sebagai orang asli Papua. Keputusan MRP yang menyatakan Komaruddin Watubun bukan orang asli Papua menandakan bahwa MRP tidak menghormati hak-hak masyarakat hukum adat yang telah diakomodir dalam Pasal 18-B ayat(2) UUD 1945 dan Pasal 1 huruf $r$ serta Pasal 1 huruf t UU Otsus Papua.

Seharusnya MRP memaknai rumusan Pasal 1 huruf $\mathrm{t}$ dan landasan filosofis, konstitusional dan yuridis pembentukan UU Otsus Papua. Landasan filosofis yaitu bahwa dalam rangka mengurangi kesenjangan antara Provinsi Papua dan provinsi lain, dan guna meningkatkan taraf hidup masyarakat di Provinsi Papua serta memberikan kesempatan kepada penduduk asli papua, diperlukan adanya kebijakan khusus dalam kerangka Negara Kesatuan Republik Indonesia. Demikian juga bahwa pemberian Otonomi Khusus bagi Provinsi Papua dimaksudkan untuk mewujudkan keadilan, penegakan supremasi hukum, penghormatan terhadap HAM, percepatan pembangunan ekonomi, peningkatan kesejahteraan dan kemajuan masyarakat Papua dalam rangka kesetaraan dan keseimbangan dengan kemajuan provinsi lain. Oleh karena itu lebih lanjut dinyatakan dalam bagian penjelasan umum UU OtsusPapua bahwa tujuan utama pembentukan UU Otsus-Papua adalah untuk menempatkan Orang Asli Papua dan penduduk Papua pada umumnya sebagai subyek utama dalam pembangunan pemerintahan di Provinsi, Kabupaten/Kota di seluruh wilayah Papua dalam rangka pemberdayaan kemanusiaan.

Landasan Konstitusional yaitu bahwa dalam UUD Tahun 1945 meliputi (a) Pasal 18-B Ayat (1) ; (b) Pasal 18-B ayat (2) dan Pasal 28-H menentukan bahwa Setiap Orang berhak mendapat perlakuan yang khusus untuk memperoleh kesamaan dan manfaat yang sama guna mencapai persamaan dan keadilan.

Dimyanti hartono menyebutkan bahwa agar suatu produk hukum dapat diterapkan dengan baik didalam masyarakat diperlukan tidak hanya rechmatigheid atau dasar hukum yang benar, tetapi juga doelmatigheid atau tujuan yang hendak dicapai dalam pembuatan dan penegakan hukumnya pun harus benar, sebab 
rechmatigheid berarti norma-norma tentang kebenaran, dasar-dasar tindakan, kewenangan,cara bertindak yang dibenarkan oleh Grundnorm, yang termasuk juga didalamnya cara mencapai tujuan tersebut (Dimyanti Hartono; 1997: 17)

Dalam hal pembentukan suatu Peraturan perundangan-undangan yang baik hal yang perlu diperhatikan dalam pembentukan Peraturan perundang-undangan yang baik. Dalam Pasal 6 UU No 11 Tahun 2011 asas-asas tersebut meliputi asas-asas:
a. Pengayoman.
b. Kemanusian.
c. Kebangsaan.
d. Kekeluargaan.
e. Kenusantaraan.
f. Bhineka Tunggal Ika.
g. Keadilan.
h. Kesamaan kedudukan dalam hukum dan Pemerintahan.

i. Ketertiban dan kepastian hukum; dan/ atau

j. Keseimbangan, Keserasian, dan keselarasan.

Asas-asas hukum ialah dasar -dasar atau petunjuk arah (richtlijn) dalam pembentukan hukum positif, dalam arti asasasas hukum berguna untuk praktik hukum (Yuliandri; 2010:163)
Asas-asas hukum dalam pembentukan Peraturan perundang-undangan adalah untuk memberikan arahan yang seharusnya diikuti oleh para pembentuk peraturan perundang-undangan yang baik (rechmatig) dalam penyusunan peraturan perundang-undangan yang baik sebagai suatu aturan hukum agar produk hukum yang dihasilkan ketika dalam penerapannya dapat diterima oleh masyarakat.

$$
\text { Apabila demikian halnya }
$$

pemerintahan daerah dalam menafsirkan substansi UU Otsus-Papua serta menjalankan UU Otsus- Papua berdasarkan wewenang intitusional tanpa berdasarkan pada UU Otsus-Papua maka dari segi kemanfaatan dalam penerapannya dilapangan hukum UU Otsus tidak bersifat responsive/populastik. Tindakan MRP dalam mengeluarkan Keputusan No.06/MRP/2005 dinilai merupakan tindakan penegakan hukum secara affirmative bagi pelaksanaan UU OtsusPapua, namun tindakan tersebut harus disingkronisasikan dengan substansi UU Otsus lainnya dan aturan hukum lainnya berdasarkan Groundnorm. UU Otsus-Papua secara substansi harus memiliki kekuatan hukum mengikat dan norma hukumnya tidak boleh menimbulkan multiinterpretasi, norma hukumnya harus pasti baik secara vertical 
maupun horizontal, akibat lemahnya norma hukum UU Otsus Papua hal tersebut dapat memberikan ketidakpastian hukum. Hak Masyarakat adat suku Yawa Onate merupakan hak adat yang telah memperoleh kekuatan hukum tetap berdasarkan konstitusi dan UU Otsus-Papua. Dari segi Hierarki Peraturan perundang-undangan UU Otsus -Papua secara substansi tidak boleh bertentangan dengan Konstitusi ( UUD 1945) . Konstitusi merupakan norma hukum dasar dalam penyusunan peraturan perundang-undangan lainnya. Hal yang perlu dipahami oleh seluruh organ pemerintahan daerah (MRP, DPRP dan Gubernur) bahwa sekalipun semangat penyelenggaraan Otonomi Khusus di
Provinsi Papua adalah wewenang secara atribusi/wewenang asli /wewenang yang diperoleh secara langsung dari Pasal 18-B ayat (1) UUD 1945, namun pelaksanaanOt onomi Khusus bukanlah suatu kemerdekaan penyelenggaraan pemerintahan daerah tanpa bersyarat. Frasa kewenangan tidak dapat disamakan dengan "kebebasan" bertindak secara sewenang-wewenang sesuai dengan kehendak pemerintahan daerah Penyelenggaraan pemerintahan daerah masih tetap menggunakan UU No.32 tahun 2004, hal ini menunjukan bahwa perlu adanya singkronisasi peraturan perundangundangan secara vertical maupun horizontal. 


\section{BAB III \\ KESIMPULAN}

1. Kedudukan hukum (legal

Kabupaten Serui telah memenuhi standing) masyarakat hukum adat Yawa Onat sebagai pemohon dalam uji materil UU OtsusPapua di Mahkamah Konstitusi didasarkan Pada :

syarat-syarat materil dalam Pasal 51 ayat (1).

2. Dalam rangka harmonisasi peraturan perundang-undangan secara vertical maupun horizontal

- pertimbangan filosofis, konstitusi dan landasan yuridisme pembentukan UU Otsus-Papua No.21 Tahun 2001;

- Pasal 51 ayat (1) dan penjelasan Pasal 51 ayat(1) UU MK No.24 Tahun 2003;

- Pasal 1 huruf t dan Pasal 1 huruf $r$ UU Otsus Papua No.21 tahun 2001.

Prosedur pengujian Pasal-Pasal dalam UU Otsus -Papua No.21 Tahun 2001 oleh masyarakat maka setiap norma hukum yang termuat dalam Pasal \& ayat UU Otsus-Papua hendaknya disusun sedemikian dengan mengikuti tata cara penyunan peraturan perundang-undangan yang berlaku (hierarki norma) dengan tidak boleh mengabaikan asasasas penyusunan peraturan perundang-undangan yang baik, hal tersebut dimaksudkan agar dalam penerapannya UU OtsusPapua tidak lagi menimbulkan konflik dan multi interpretasi hukum adat Yawa Onat- 
dalam norma-norma hukum khusus tersebu

\section{DAFTAR BACAAN}

Donikus Rato, 2011, Hukum Adat (Suatu Pengantar Singkat Memahami Hukum Adat di Indonesia Laksbang, Yogyakarta

Fatmawati, 2004, Hak menguji (Toetsings recht) yang dimiliki Hakim Dalam Sistem hukum, Raja Grafindo Persada.Jakarta

Hilman Hadi Kusuma,1980, Pokok-Pokok Pengertian Hukum Adat, Alumni Bandung.

Soebakti Poesponoto, 1985, Asas-asas dan Susunan Hukum Adat, Pradnya Paramita, Jakarta

Titik Triwulan Tutik, 2010, Konstruksi Hukum Tata Negara Pasca Amandemen UUD 1945, Prenada Media Group.Jakarta
Yohanes Usfuna,Makalah uji Materi Pasal 20 ayat (1) huruf a UU Otsus Papua di Mahkamah Konstitusi, Jakarta

Yuliandri, Asas-Asas Pembentukan Peraturan Perundang-undangan yang Baik; Gagasan Pembentukan UndangUndang Berkelanjutan, PT Raja Grafindo Persada, Jakarta.

Rainer Scheunemann ., 2004, Fajar Merekah Di Tanah Papua"Hidup Dan Karya Rasul Papua Jhonn Gottlob Geissler (1830-1870) Dan Wasisannya Untuk Masa Kini.Jayapura

H.Lili Rasjidi \& I.B.Wyasa Putra., 2003. Hukum sebagai suatu system. Mandar Maju, Bandung

Dimyanti Hartono.M.,1997, Lima Langkah Membangun Pemerintahan yang Baik, IND HIL.CO Jakarta. 